\title{
Hafıza Arakesitinde Yazınsal Mekânın Göstergebilimsel Anlatısı
}

\author{
Tuğçe Gürleyen ${ }^{1}$ \\ ORCID: 0000-0001-6091-8524
}

Öz

Göstergebilim incelemelerinin önemli bir basamağın oluşturan metin ve söylemler, kişinin düşüncesini ifade etmek için kullandığı dil kodlarıdır. Sürekli olarak yenilenen ve devinen söylemler, sözel ve görsel anlatımın zaman dizilim ilişkileri içinde, farklı katmanları ayrıştırarak kentsel anlam ve hafizanın bir süreç boyunca analiz edilmesine olanak să̆lamaktadır. Böylece, her dilin semiyotik haritasında olduğu gibi her mekânın hafıza haritasında farkl görüngüler oluşmaktadır. Bu bağlamda edebi kurgu, hafiza ile mekânlar arasındaki ilişkileri güçlendiren bir metin görevi görmektedir. Metnin içerdiği özgün ayrumlar, silikleşen ve üst üste binen palimpsest hafıza izlerini ortaya çıkarmaktadır. Kentsel/mimari tasarımın edebiyatla olan ilişkisi, anlama, hayal etme, üretme ve tasavour etme becerisini geliştiren önemli birer araçtır. Yazınsal mekân üretimi, insanın düşünceleri, anıları ve düşleri için en büyük birleştirici güçlerden biridir. Bu çalışma, edebiyat, mekân ve hafiza arasındaki ilişkiye odaklanmakta, kentsel bağlama metinsel kurguyu ekleyebilmenin ve edebiyatın düşsel kurgusu ile tasarmm anlatı gücünü birleştirmenin önemini vurgulamaktadır. Bu çerçevede, yazınsal mekânın anlatısı ve metinler aracılı̆̆ıyla ortaya çıkarılan mekân kurgusu, seçilen farklı örnekler üzerinden incelenmiştir. Bu örnekler, sundukları farklı temsil biçimleriyle hafizanın barındırdığı anlamları ortaya koymaktadır. Metinler aracılığı ile yapılan göstergebilimsel anlatı ve görsel temsilleri, kentsel/mimari mekânın üretimine doğrudan katkı sağlamaktadır.

Anahtar Kelimeler: Yazınsal mekân, göstergebilim, hafiza kodlan, görsel temsiliyet 


\title{
Semiotic Narrative of Literary Space in the Intersection of Memory
}

\author{
Tuğçe Gürleyen² \\ ORCID: 0000-0001-6091-8524
}

\begin{abstract}
The texts and discourses that constitute an important step of semiotics studies are the language codes used to express one's thought. Continuously renewed and moving discourses allow the analysis of urban meaning and memory. Thus, as in the semiotic map of each language, different perspectives occur in the memory map of each space. In this context, literary fiction acts as a text that strengthens the relations between memory and spaces. The unique distinctions in the text reveal palimpsest memory traces. The relation of urban/architectural design with literature is an important tool that develops the ability to understand, imagine, produce and envision. The production of literary space is one of the biggest unifying forces for human thoughts, memories and dreams. This study focuses on the relationship between literature, space and memory. It emphasizes the importance of adding textual fiction to urban context and combining the imaginative fiction of literature with the narrative power of design. In this context, the narrative of the literary space and the space fiction created through texts were analysed on different examples. These examples reveal the meanings of memory with the different representation forms. Semiotic narrative and visual representations contribute directly to the production of urban/architectural space.
\end{abstract}

Keywords: Literary space, semiotics, memory codes, visual representation 


\section{Giriş}

Mekânlar, çok katmanlı yapısı gereği birbirinin üstünden beslenen veya ardıllarda gizlenen çeşitli göstergelerden oluşmaktadır. Kentsel yaşamın içine sızan ve zihinlerde yer edinen mekânsal kodlar ve imgeler, kentin ortak anlamına ve hafızasına ilişkindir. Toplumun ortak belleğinde farkında olmadan, istemsizce oluşan kentsel kodlamalar, kendi karakteristik metinlerini üreten yaşam alanlarının içinde kullanılan dil ile varlı̆̆ını sürdürmektedir. Dili anlama ve kullanma yetisi, deneyimleri ve eylemleri birbirine bağlarken, aynı zamanda değerlerin ve anlamın yeniden üretimine karşlık gelen yeni mekânsallıklar sunmaktadır.

Yazınsal mekân, gündelik yaşantıda yer alan çeşitli karakterlerin ve eylemlerin dil aracilı̆̆yla sözel ve görsel bir temsilidir. Mekân yaratmanın bir yolu olarak metinler, gündelik yaşamla var olmakta ve yeniden kurgulanmaktadır. Metinde oluşturulan mekânın tekrar kurgulanması, yorumlayanın kendileştirme sürecine ve imgeleri yaratma gücüne bağlıdır. Diğer bir ifadeyle, mekânsal anlatı, sadece yazarın biçimlendirdiği şekilde değil yorumlayanın oluşturduğu imgeler üzerinden algılanmakta ve eklemlenen imgelerin anlamsal bütünlüğüne bağlı olarak yeniden üretilmektedir. Dolayısıyla, kendi içinde mekânlar yaratan metinlerin dinamik yapısını deneyimler oluştururken, metnin yaşaması ve mekânlarla var olması hafızayla mümkün olmaktadır.

Bu çalışma, edebiyat, mekân ve hafıza arasındaki ilişkiye odaklanmakta, kentsel bağlama metinsel kurguyu ekleyebilmenin ve edebiyatın düşsel kurgusu ile tasarımın anlatı gücünü birleştirmenin önemini vurgulamaktadır. Yazınsal metinlerin kentsel/mimari mekânı sorgulama, tasarlama ve çözümleme aracı olarak kullanılmasının ve temsil edilmesinin gereğini ortaya koymaktadır. Çalışma kapsamında, yazınsal mekânın anlatısı ve mekânların hafızadan gerçekliğe dönüşümü, seçilen farklı görsel temsiller üzerinden incelenmiştir. Metnin yorumlanma sürecinde yorumlayanın zihninde oluşan göstergelerin farklı görsel temsiller ile aktarımı, bağlam, işlev ve hafıza taşıyıcıları başlıkları altında değerlendirilmiştir.

\section{Edebiyat, Mekân ve Hafıza İlişkisi}

Bir yerin hafiza değeri, insanların mekânsal fikirleri ve betimlemeleri ile bağlantılıdır. (Rossi, 1983)

Kentsel/mimari mekânın edebiyatla olan ilişkisi, romantik bir yaklaşım olmanın ötesinde, anlama, hayal etme, üretme ve tasavvur etme becerisini ge- 
liştiren önemli birer araçtır. Mekânın metinde veya okur/kullanıcı düzleminde yeniden üretilmesi, çağın ruhunu taşıyan ortak bir dilin oluşturulması, kodlar, referanslar ve çağrışımlar aracılığıyla toplumsal değerlerin, eylemlerin ve inanısların birbirine bağlanması, metinler/mekânlar arası yolculuklarda ortaklıklar sunması mimarlığın edebiyatla olan ilişkisini güçlendirmektedir (Uz, 2007).

Kentsel/mimari araştırmanın edebiyattan bağımsız olmadığını (Stein, Haldenbay ve Roth, 1990), mimarlık ve edebiyat arasındaki karşılıklı araçsal ilişkinin analiz ve çözümleme aşamasında kurulmasının faydalı olduğunu savunan görüşler (Havik, 2006; Spurr, 2012), edebi kurguyla mekânın bă̆lamsal ilişkilerine odaklanmaktadır. İnsanlar ve çevreleri arasındaki ilişki, edebi betimlemelerin ayrıntısında gizlidir. Metinlerin temelindeki evrensel ve ortak dil, edebiyatın mimari temsilini sunmaktadır.

Hegel'e (1998) göre mimarlik ve edebiyat, bireysel ve kolektif insan ruhuna ifade verme biçimlerinde birbirine tezat ama bir o kadar da tamamlayıcı iki unsurdur. Hegel' in ruh olarak tanımladığı şey mimarlığın dışlanmış hali de olsa, mimarlığın karşısına "ruhun mutlak ve gerçek sanatı" olan edebiyat çıkmaktadır. Edebiyat, içsel ruhun saf ifadesinin bütünsel olanına işaret ederken; mimarlık, başlangıç çekirdeğini oluşturmaktadır. Metinsel olma hali, geçmişi şimdiki zamana getirirken; yazınsal metni okuma, geçmişin saf varlığına ulaşmada önemli bir araçtır (Deleuze, 1994).

Metni okuma pratiğinin olabilmesi için yazma eyleminin gerçekleşmiş olması gerekmektedir. Eski çağlarda taşa kazınan yazılar, somut çevrenin önemli bir göstergesidir. Mekânsal kompozisyonun her bir ögesinin varlığı, estetik bir anlayışla yapılmış bir yazı eylemidir. Tasarım pratikleri ile görsel dile dönüşen düşünceler, anlatımla sözel dile, sonrasında yazı diline dönüşmektedir. Bu etkileşim, dilin ortak bir kavram olmasıyla yakından ilgilidir. Düşünmekten çok, düşünceyi ifade etmek için görsel, sözel ve yazınsal dili kullanmak, farklı dillerin bütünlüğüne işaret etmektedir. Düşüncenin arkasından gelen özü düşünme, kentsel bağlamın kalıcı ve varoluşsal diline işaret etmektedir (Heidegger, 2008).

Tümer (1981), kentsel/mimari mekânın dil ile kurduğu ilişkiye ve yazarların dili kullanma ve gözlem yapma becerilerine dikkat çekmekte ve bu yönüyle yazınsal mekânın niteliklerini tasvir etmede zengin birer kaynak oldukların ifade etmektedir. Böylece kentler, edebi yazınlar üzerinden yeniden gözlemlenme ve okuma şansı bulabilmektedir. Bununla birlikte, edebiyat yalnızca mekânı tasvir etmek için değil, mekânsal deneyimin yeniden şekil- 
lenmesi için aracılık etmektedir. Thomson'ın (1996) ifade ettiği gibi, kenti fiziksel olarak deneyimleme, zaman, yer ve harekete ilişkin kısıtlara bağlı olarak gelişmektedir. Ancak edebiyat, farklı kentsel ortamları başka zamanlarda yaşama olanağı sunmaktadır. Kentin şïrsel tınısına, gizli kalmış yanlarına, görünmeyen ve hayali olanı sezme ve algılama sürecine tanıklık etmektedir (Thomson, 1996). Dolayısıyla, edebiyatın fiziksel bağlamdan ayrılma özgürlüğü, kentin düşün sistemine daha zengin bir deneysel alan sunmaktadır.

Kentsel ve mimari deneyimler, doğası gereği çok boyutlu, somut ve varoluşsal bir gerçekliğe sahiptir. Pallasmaa'nın (2012) ifade ettiği gibi "retinal önyargı", insanı çevreleyen mimarinin gerçek bir fenomenolojik deneyiminin duyusal ve bedensel nitelikleri üzerine kurulmuştur. Yazma eylemi, belirli bir mesafe ve soyutlamayı ifade ederken, aynı zamanda yaşanmış deneyimleri temsil ederek kentsel çevreyi uyarmaktadır. Bu bağlamda, mimarlık ve edebiyat kurgusunun tamamlayıcı unsurları, farklı algı ve deneyimlerle birleşerek etkin hale gelmektedir (Havik, 2014; Merleau-Ponty, 2013; Thomson, 1996; Tümer, 1984).

Edebiyat, mekânın yaşanmışlıkları, zamanın rolü, hafıza ve hayal gücü hakkında temel bilgiler sunmaktadır. Edebi kurgu, hafıza ile mekânlar arasındaki ilişkileri güçlendiren bir metin görevi görmektedir. Mekânsal anlamların katmanlarına girerek yeni anlayışlar yaratmaktadır. Farklı zamansal anlatıların şiirsel rezonansı, okura çeşitli mekânsal deneyimleri yaşama fırsatı sunmaktadır (Thomson, 1996). Bu yazınsal deneyimler, mekânı anlatımsal olarak anlamanın ve hafıza izlerini ortaya çıkarmanın güçlü bir yoludur.

Edebi metinlerde kentsel anlatılar, düşler ve izlenimler zengin biriktirmelerdir. Kent mekânlarında dolaşan, onları yeniden okuyan, dönüştüren ve yenilerini kurgulayan yazar, insanları gerçek ve düş arasında mekânsal bir yolculuğa çıkarmaktadır. Joyce'un Dublin'i, Dickens'ın Londra'sı, Proust'un Paris'i, Borges'in Buenos Aires'i, Dostoyevski'nin Petersburg'u, Balzac' in Paris'i, Kafka'nın Prag' 1 , Mungan'ın Mardin'i ve Pamuk'un İstanbul'u, hafızaların, işaretlerin, yansımaların ve çok anlamlılığın bir mekâna tutunmasını anlatmaktadır. Metin kendini ifade etmenin yanı sıra, mekânın hafızasını yazı aracılığıyla katmanlaştırmaktadır.

Gerçekte var olmayan, sadece edebi metinlerde kurgulanan mekânlar, okuyucunun zihninde betimlemeler yoluyla canlanmaktadır. İlyada ve Odysseia'da, Antik dönem mekânlarının betimlemesi, kentlerin düzeni ile yakından ilişkilidir. Orhan Pamuk'un Masumiyet Müzesi, edebi metinde kurgulanan bir mekânın, somut bir mekâna dönüşmüş örneklerinden biridir. 
Dolayısıyla, edebiyat üzerinden gerçeğin betimlenmesi ve betimlemenin gerçekleşmesi mümkündür.

Metinde yaratılan karakterlerin hikâyeleri, yapılı çevrenin içinde anlatılmaktadır. Buna bağlı oluşan mekân betimlemesi ve şehirsel alanın izdüşümü metinde hissedilmektedir. Karakter veya metinsel kurguyla özdeşleşen mekânlar, birbiri içine saklanırken, aynı zamanda birbirine karışmakta, temsil etme, hikâyeleme ve yaratma bağlamında birbiri ile kesişmektedir.

Edebiyat, mekân ve hafıza ilişkisi sorgulandığında, gündelik yaşantıya dair olgular dikkat çekmektedir. Gündelik yaşantının dil ve yazı aracılığıyla düşünce ve bilinç alanına girmesiyle birlikte yazınsal mekânlar, gündelik yaşantının geçtiği mekânların niteliklerine koşut hale gelmektedir (Çağlar ve Ultav, 2004). Edebi metinde yer alan karakterlerin ve eylemlerin dil yoluyla temsil edilmesi, kentsel mekânın ideolojik bir metin olarak okunabileceğini göstermektedir (Lefebvre, 1993).

Böylece yazınsal dil, mekânın anlamını ve temsiliyetini pekiştirmektedir. Mekânsal pratiklerin hikâye kurucu olma özelliği kentsel mekânın hafızaya alma sürecini desteklemektedir (De Certeau, 1984). Kırılganlaşan ya da sürekliliği olan mekânsal izlerin hafızaya alınması metinsel bir arakesitte okunabilmektedir. Dolayısıyla, edebiyat, hafıza ile mekânlar arasındaki ilişkileri güçlendiren bir metinsel repertuardır (Uz, 2007).

\section{Göstergebilim ve Metinlerarasılık Ekseninde Yazınsal Mekân}

Kulaklarınıla işittiğiniz renkler; gözlerinizle gördüğünüz sesler; avuçlarınıla dokunduğunuz boşluklar; dilinizdeki mekânın tadı; ölçülerin güzel kokusu; taş'ın özsuyudur.

(Breuer, 1986)

Dilbilimsel kuramın (yapısalcılık, göstergebilim, yapısökümcülük) disiplinlerarası niteliğinin güçlü olması, akademik çalışmaların sınırını genişletmiştir. Kentsel/mimari mekâna dair üretilen bilginin yazınsal metinler üzerinden okunması, kentbilim araştırmalarında ele alınan dilbilimsel yaklaşımlardan biridir. Kentsel/mimari bir bilinç ve kaygı duymadan yazılan eserlerden yararlanma ve duyarlı bir gözlemci olan yazarın mekânsal konulara yaklaşımını öğrenme eğilimi (Tümer, 1984) kente dair geniş bir çalışma alanı ve kaynak sunmaktadır. Metinde sorgulama aracı olarak üretilen anlam, tasarım sürecine esin kaynağı olmaktadır.

Yapısalcılık, tarihsel bir olay ve düşüncenin evrimsel gelişiminden ziyade, belli bir zaman dilime ait olan an'ın yapısını ve anlamını oluşturan eşzamanlı ögelerin karşılıklı ilişkilerini ele alan kuramsal bir yaklaşımdır. Yapısalcılığın 
kökeni, Saussure'ün Genel Dilbilim Derslerinde (1998) aktardığı dilbilim kuramına dayanmaktadır. Saussure (1998) dilin artzamanlı (diachronique) değil eşsüremli (synchronique) kesitine ait bir yapının, göstergeler sistemi olduğunu ileri sürmektedir. Göstergenin yeniden anlamlandırılma süreci, benzerlikler ve farklılıkların sınıflandırılmasıyla ilişkilendirilmiştir. Her bir gösterge; gösteren (imge ve grafik eşdeğeri) ve gösterilenden (kavram ve anlam) oluşmaktadır. Bu iki bileşen arasındaki ilişki, göstergeler üzerinden okunabilmekte, böylece dilin yapısı çözümlenmektedir. Çözme etkinliğinin yanı sıra yeniden kurma ve yapılandırma eylemlerini de içinde barındırmaktadır. Yapısalcı yaklaşımın öncülüğündeki kent okumaları, bir kentin yapısını işaretlemekte ve kodlar üzerinden çözümleme ve metne dökme amacını taşımaktadır.

Edebi metin, dil düzeyinde toplumsal ve ekonomik sorunlara tepki gösteren, anlamlı, sözdizimli ve anlatısal yapılar toplamıdır. Dil, metin ve göstergeler dizgesi olarak kavranabilecek toplum arasinda konumlanan arac bir basamaktır (Zima, 2000). Göstergebilimde yazınsal metinler, anlam aktarıcı bir yapılanmadır (Barthes, 2005). Yapılanma için gerekli olan, metindeki karakterin başlangıç noktası, özüdür. Dilin semboller aracılığıyla ifade edilmesi, aktarılması ve kalıcılık kazanmasıdır. Bir metin içinde var olan anlam dizgelerini göstergeler aracılığıyla okuma, kodları anlamlandırma, dizi, dizim ve metafor ile metinlerarası ilişkileri değerlendirme, ima edilen anlamların altında yatan ideolojiyi ve kültürü arama göstergebilimsel okuma yönteminin temelini oluşturmaktadır. Edebî göstergebilim (literary semiotics), gösterge ve bildirişim kuramlarını metinlere uygulamaktadır. Bu çerçevede, metin çözümlemesi (textual analysis), anlatı çözümlemesi (narrative analysis), yapısal çözümleme (structural analysis) ve söylem çözümlemesi (discourse analysis) gibi yöntemler kullanılmaktadır.

Peirce'nin (1991) göstergeler sistemi sinıflandırmasinda, belirti (indices), görüntüsel gösterge (icon) ve simge (symbol), bağımsız özgün bir dil oluşturmaktadır. Görüntüsel gösterge, belirtilen işaretin doğrudan temsilini ifade ederken; belirti, nesnesi ortadan kalktığında kendisini gösterge yapan özelliği hemen yitirecek olan ama yorumlayan bulunmadığında bu özelliğini yitirmeyecek olan göstergedir. Simge ise yorumlayan olmasaydı kendisini gösterge yapan özelliği yitirecek olan bir göstergedir. Bu açıdan, gösterge (sign), göstergenin gönderimi (reference) ve göstergeyi yorumlayan kişi (human interpreter) arasındaki bağıntı önem kazanmaktadır (Moloney, 1983). Bu bağlamda, anlamın ve simgenin oluşumu (gösterge) ve insanların yarattığı doğal 
dillerin ve işaretlerin aktarımı (gönderim), toplumsal değerlere (yorumlayan) bağlı gelişmektedir.

Derrida'nın (1997) "metnin dışında hiçbir şey yoktur" önermesi, yapısökümcü anlayışın temelini oluşturmaktadır. Bu anlayış, metinlerin birden fazla anlamı olduğunu, tek ve mutlak bir anlam bulunmadığını ifade etmektedir. Buna paralel olarak, yapısöküm yöntemi tek ve mutlak bir doğru anlayışını ve inancını yıkmaya çalışmakla birlikte bütünlügün nasıl inşa edildiğini anlamaya yönelmektedir. Saussure'ün (1998) ortaya koyduğu gösteren ve gösterilen arasındaki ilişki, yapı söküme uğratılarak ötekinin önemi vurgulanmıştır. Derrida (1997), yapısöküm tekniğini oluştururken en çok ayrım ve iz kavramlarını kullanmıştır. Dili oluşturan parçaların izlerini inceleyerek görsel imlere (işaretler) odaklanmıştır. Böylece, metnin içerdiği özgün ayrımlar, silikleşen ve üst üste binen hafıza izlerini ortaya çıkarmaktadır.

Barthes'ın (2005) geliştirdiği yapısal çözümleme yöntemi, kültürel anlamlar taşıyan göstergelerin dizgeleri arasındaki bağlantılara dayanmaktadır. Barthes'ın "her metnin eski alıntıların bir örgüsü olduğu" saptaması göstergebilime dair düşüncesinin genel çerçevesini oluşturmaktadır. Bakhtin'in (1984) öne çıardığı "metinlerarası ilişkiler" kavramına paralel olarak, Kristeva'nın (1980) göstergeçözüm ve anlamçözüm olarak adlandırdığı metin çözümleme yöntemlerine benzer nitelikler göstermektedir. Bir metnin eşsüremli ve artsüremli boyutlarda başka metinlerle ilişkilendirilmesi anlamına gelmektedir.

Metinlerarasılık kavramı, metinlerin temel kaynaklarından birinin önceki metinler olduğu düşüncesine dayanmaktadır. Yazınsallığın ölçütü olan metinlerarası söylemler, edebiyatta metinlerin kendinden önceki metinlerden bağımsız düşünülemeyeceği, her metnin başka metinlerin biraradalığından oluştuğu ve metinsel bir ifadeyi anlamlandırmanın ancak öncülleri ile kurdukları ilişkilerle mümkün olduğu anlamına gelmektedir. Buna göre, edebi metin, farklı ilişkiler ile yeni bir bağlamda bir araya gelen öncel metinlerin toplamıdır (Aktulum, 2000). Bir başka ifadeyle, metinler başka metinlerin alıntılanması veya anlamsal, yapısal ve biçimsel yönden dönüştürülmesiyle oluşmaktadır.

Metinlerarası ilişkiler, okuyucunun geçmiş deneyimleri, kültürel bakış açısı, beklentileri ve birikimleri ile doğrudan ilişkilidir. Katmanlar arasında oluşan ve çoğul okumaya olanak sağlayan anlam düzlemleri (Eco, 2009), okuyucunun kendi birikimine bağlı olarak farklılaşmaktadır. Anlam derinliği, gösteren ve gösterilen arasında oluşan enerji, hafıza diyalektiğine farklı açı- 
lımlar sunmaktadır. Metinlerin üst üste eklenmesi ile oluşan çok katmanlı palimpsest yapı, mekânsal anlatıları bir araya getirmektedir. Dolayısıyla, eski ve yeni metinler arasında zamanın yok edemediği bir "sürerlilik" ve "bütünlük" sağlanmaktadır (Genette, 1997).

Anlam üreten her bir olgunun metin olduğu düşüncesi (Barthes, 2005; Lefebvre, 2004; Ricoeur, 2010) göstergebilimin sınırını genişletmiştir. Metinlerarası bağlamda değerlendirilen toplumsal işaretler, kodlar ve düğüm noktaları dilbilimsel çalışmalar çerçevesinde ele alınmaya başlanmıştır. Yer aldığı dönemin, kültürün ve kodların izlerini taşıyan yazınsal mekân üretimi, yazarın gözlemleri, imgelemi ve anıları üzerinden yeniden yapılandırılmıştır. Böylelikle, okuyucu, düşünsel mekânlar ve yaşantılar arasında zihinsel olarak dolaşmakta, kendi düşünsel kurgusunu yaratmaktadır (Werth, 1999).

Bachelard'ın (1996) yazınsal mekânı, insanın düşünceleri, anıları ve düşleri için en büyük birleştirici güçlerden biridir. İnsanlar mekânları yeniden üretirken, mekânlar insanların hatıralarını, duygularını ve düşüncelerini biçimlendirmektedir. Şiirsel imgelem, insan ve mekânı dolayımsız bir şekilde birbirine bağlamaktadır. Metinde yoruma dayanan, akılda tutulan, gönderme yapılan, gizil veya üst üste gelen, çelişen, ayrıklaşan "almaşık anlamlar kümesi" (Fairclough, 1992) mekânın ve öznenin imgeler üzerinden inşa edildiğini göstermektedir. Bu göstergeler, düş mekânı ile düş zamanını anlatan hafıza kodları olarak okunabilmektedir (Borgeaud, 1999). Mekânı "yap1bozumsal" yıkan ve ardından yeniden kuran bu metinler, hafiza, anlam ve düş üzerinedir.

Yazınsal mekânın okuyucunun hayal ve alımlama gücüne bağlı yeniden anlamlandırılması, anlatıların kendi iç dinamikleri ve öteki ile kurdukları ilişkiyi göstermektedir. Bu bağlamda, metinlerarası ilişkilerin neden ve nasıl kurulduğunun analizi, farklı öznelerin yeni bir bağlamda kendi döneminin koşullarına göre mekânı üretme şekillerini okumaya yardımcı olmaktadır. Böylelikle, okuyucu, yazınsal metinlerden içgüdüsel olarak algıladıklarını, güvenilir ve güçlü dilbilimsel kanıtlara dayandırmaktadır (Çağlar, Tuna Ultav ve Boyacıoğlu, 2013).

\section{Yazınsal Mekânın Göstergebilimsel Anlatısı ve Görsel Temsilleri}

Edebi metinlerin göstergebilimsel anlatısı, hatırlama, anlam kazanma ve yaşanmış deneyimleri yeniden yapılandırma bağlamında üst üste eklemlenerek birbiri ile örtüşen mekânların, imgelerin ve farklı temsiliyet biçimlerinin çok sesliliğini yansıtmaktadır. Toplumsal yaşamı ve mekânı birlikte anlamanın ortak yollarını oluşturan ve hafızanın yeniden üretimine karşılık gelen etkin 
bir araçtır (Bruner, 1986; Ricoeur, 2010; Wertsch, 2002). Metinlerin göstergebilimsel analizi sonucunda oluşan görsel temsiller, geçmişi yeniden yapılandırmanın, bireysel ve kolektif deneyimleri aktarmanın ve katmanlar arası ilişkileri anlamlandırmanın bir yoludur (Crang, 1996). Geçmişi arşivlediği kadar geleceğe dair öngörüler de sunmaktadır. Sosyal ve kültürel ifade veya inşa aracı olarak kullanılmaktadır. Yorumlayanın hayallerini, fikirlerini ve duygularını yansıtmaktadır.

Çalışma kapsamında, edebi metinlerin göstergebilimsel anlatısı ve mekânların hafızadan gerçekliğe dönüşümü, seçilen farklı örnekler üzerinden incelenmiştir. Metnin yorumlanma sürecinde yorumlayanın zihninde oluşan göstergelerin farklı görsel temsiller ile aktarımı bağlam, işlev ve hafıza taşıyıcıları başlıkları altında değerlendirilmiştir. Eskiz planlar, kavramsal diyagramlar, illüstrasyonlar, mimari çizimler, maketler, aksonometrik perspektifler, grafik motifler, kolajlar, güzergâh haritaları, şehir planları ve etkileşimli web arayüzleri farklı görsel temsillere örnek oluşturmaktadır. Bölgesel, kentsel, mimari ve sokak ölçeği olmak üzere farklı bağlamları yansıtmaktadır. İfade etme, yerine geçme, tasvir etme, soyutlama, akılda canlandırma, yeniden sunma, dikkat çekme, yönlendirme, düşünsel ve duygusal durumu ortaya çıkarma, benzerlik kurma, bilgilendirme ve betimleme işlevlerine karşılık gelmektedir. Hafıza taşıyıcıları olarak ele alınan mekânsal izler, toplumsal işaretler, zihinsel imgeler, çağrışımlar, hayal gücü, mekânsal düğümler, deneyimler, duyular, gündelik tekrarlar, geçmiş izleri ve yerel hikâyeler, zamanla azalan veya göz ardı edilen detayları, toplumsal olayları ve bireylerin yer ve mekânlar için anlamlarının derinliğini ortaya çıkarabilmektedir.

İlk olarak, Ballard'ın metin kurgusu, çoğunlukla mimar olan kahramanın var olan yapılı çevre ile psikolojik, bedensel ve sosyal anlamdaki mücadelesi üzerine kuruludur. Yapılı çevreye karşı değişen eğilimler ve geleceğe dönük mekân anlayışı, tasarım bilgisinin üretilmesinde öncü rol oynamaktadır. Söylemleri, gelecekten çok hâlihazırın karşıt bir yeniden üretimini içermektedir. Ballard'ın eleştirel tutumu, içinde yaşadığımız yapılı çevreyi tümden değiştirmeye ya da ortadan kaldırmaya dair olan tasarım ideallerinin aksine, varolanın olanaklarını, potansiyellerini tanıyarak onlardan beslenen daha ucu açık bir tasarım yaklaşımını içermektedir. Bu görüş, kentleri bir anlatı biçiminde çözümlemeye çalışan güncel tutumla paralellik göstermektedir. $\mathrm{Bu}$ noktada, bağlamla kurduğu ilişki açısından yol göstericidir. 


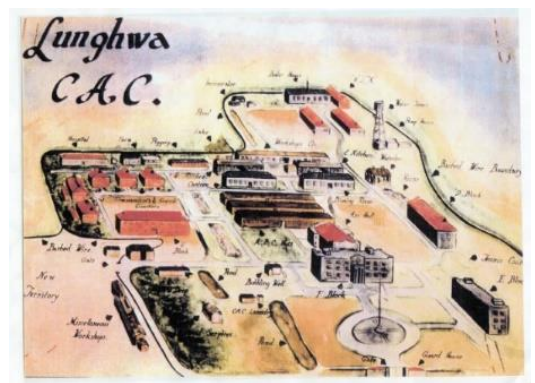

Şekil 1. Ballardian Mekânının Görsel Temsili, Lunghwa (Kaynak: Sellars, 2012)

Ballard'ın tasvirlediği mekânların atmosferi, İngilizceye "ballardian” kelimesini kazandırmıştır. Ballardian, teknolojik, sosyal ya da çevresel değişimlerin yol açtığı psikolojik sorunlara işaret eden distopik mekânlar ve insan yapımı iç karartıcı manzaralar anlamına gelmektedir. Şekil 1'deki Ballardian mekânının görsel temsili, düşünce üretme kaynaklarını çoğaltırken, bir yandan kendine özgü bir etki alanı oluşturmaktadır. Kentsel bağlamda eskiz plan ve kavramsal diyagram aracllı̆̆ ile temsil edilen mekân kurgusu, ifade etme ve yerine geçme işlevlerini yansıtmaktadır. Geçmiş kurgusu ile gelecek öngörüsü arasındaki geçişlilik, mekânsal izler ve toplumsal işaretler yard1mıyla temsil edilmektedir. Bu durum, hafızanın geriye ve ileriye dönük yönünü göstermektedir.
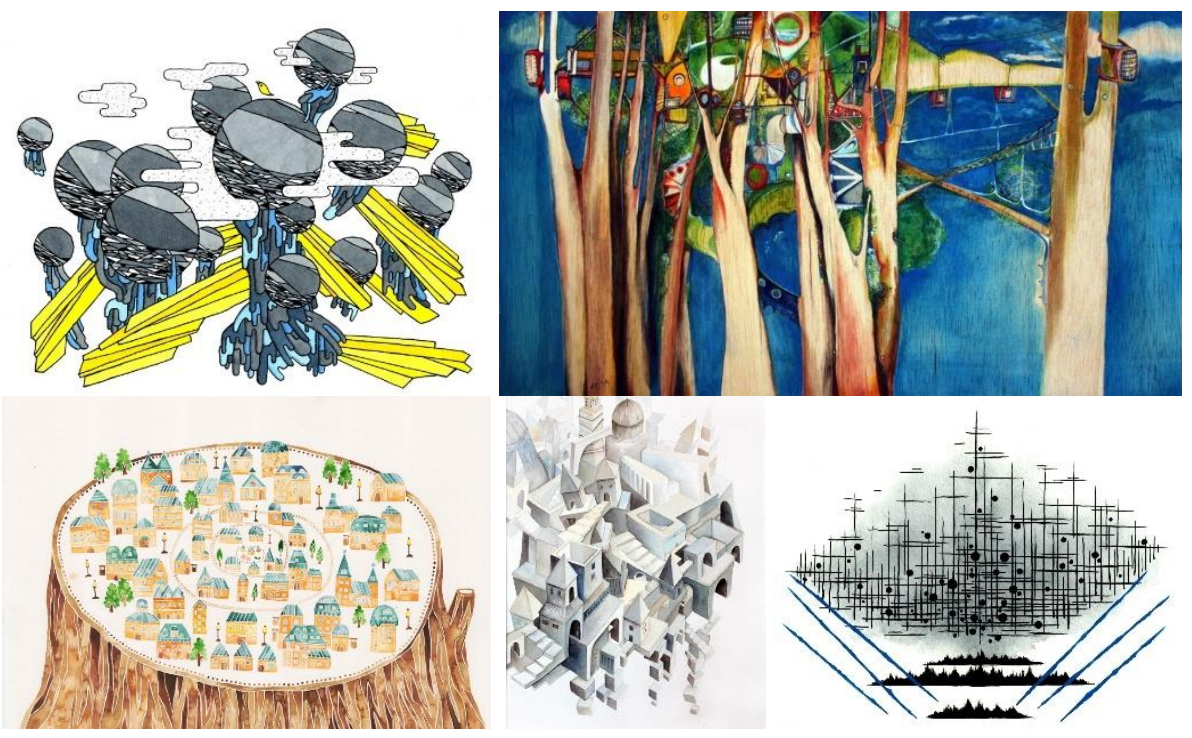

Şekil 2. Calvino'nun Görünmez Kentler' inin Görsel Temsilleri (Kaynak: Temple, 2017) 
Calvino'nun (1994) 2000'li yıllar için önerdiği altı öğesini kentsel ve mimari bir gözle okumak, mekânın temsiline yönelik önemli kazanımlar sunmaktadır. Hafiflik (varlığa yüklenen ağırlığın hafiflemesi, mizahi bir duruş sergileme), hızlılık (bedenin hafıza ile hareketi), kesinlik (olduğu gibi ifade etme), görünürlük (hayal gücü ve hafızanın temsilleriyle görünür olma), çoğulluk (aynı anda, farklı şekillerde algılama yeteneğine sahip olma, birbirine karışma), tutarlılık (çelişmeme, yan yana uyum içinde olma) ögeleri, sözel, düşünsel ve kurgusal anlamda mekâna zengin bir içerik ve bütünsel bir bağlam sunmaktadır.

Şekil 2'deki Italio Calvino' nun Görünmez Kentler' inde betimlenen yazınsal mekânın görsel temsilleri, görünürlük, çoğulluk ve tutarlılık ögelerini yansıtmaktadır. Düşünce ve hayal gücü ile kendine özgü bir dizge yaratırken, hatırlama ile mekân arasında organik bir bağ kurmaktadır. Kentsel bağlamda illüstrasyonlar ve kavramsal diyagramlar yoluyla temsil edilen mekân kurgusu, tasvir etme ve soyutlama işlevlerine karşlık gelmektedir. Zihinsel imgeler, çağrışımlar ve hayal gücü, hafızanın aktarımında etkin rol oynamaktadir.

Mimar ve yazar Matteo Pericoli öncülüğünde, dünyanın çeşitli yerlerinde atölyeler düzenleyen Lab Lit Arch Projesi (2017), edebiyata ve mimariye yeni bir bakış açısı getirmektedir (Şekil 3, 4). Mimarlık ve edebiyat disiplinlerinin benzerlikleri üzerinden görsel temsiliyetin potansiyellerine dikkat çekmekte, mimarlık ve edebiyat arakesitini yaratıcı yapma eylemi üzerinden tartışmaya açmaktadır. Lab Lit Arch Projesi kapsamında katılımcılar, birçok edebi metni kendi düşsel kurguları ile zenginleştirerek yeniden yorumlamıştır. Edebi metinlerde oluşturulan mekânların yeniden kurgulanması, okurun kendileştirme sürecine ve imgeleri yaratma gücüne bağlı olarak gelişmiştir. 


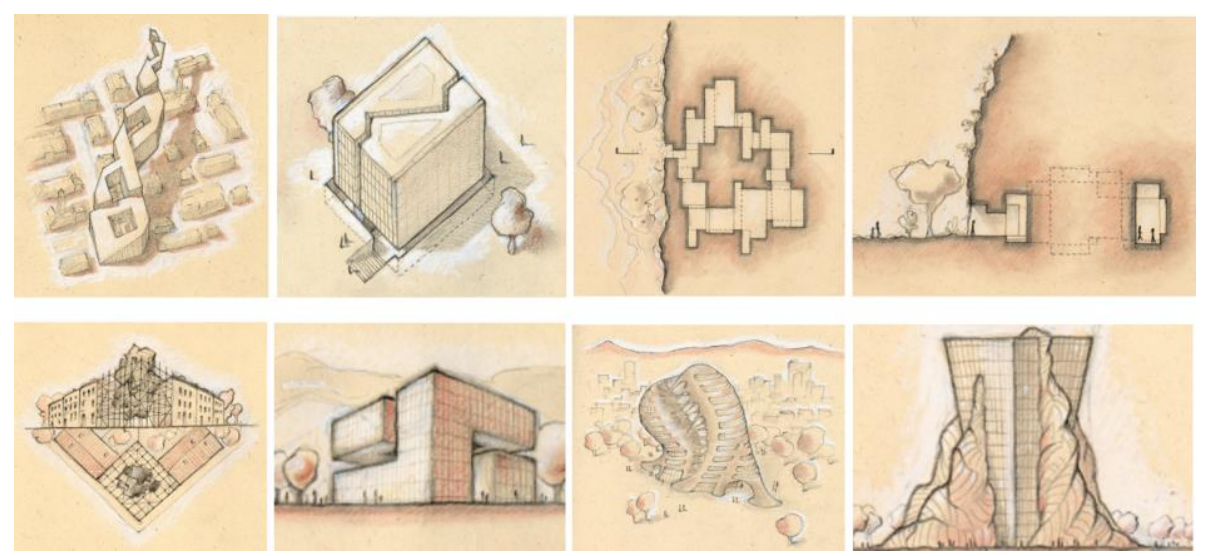

Şekil 3. Dostoyevsky'nin “Beyaz Geceler"; Italo Calvino' nun "Ağaca Tüneyen Baron”; Juan José Saer'ın “Görgü Tanığı”; William Faulkner'ın “Ölürken” Metinleri Bağlamında

Yazınsal Mekânın Görsel Temsili (Pericoli, 2017)

Dostoyevsky'nin “Beyaz Geceler"inde temsil edilen yazınsal mekân kurgusunda, güneş ışılarını yakalayabilen, uzak ve soluk bir şehir görünümü hâkimdir. Şehir dokusu, boşlukların üzerindeki gökdelenlere karışmakta ve beklenmedik bir hatıra yaratmaktadır. Italo Calvino'nun "Ağaca Tüneyen Baron"ında hikâyenin başkahramanı Cosimo'nun içgüdüsel isyan hareketi, ara boşluk ihtiyacı ve bunun sonucunda ağacın tepesine yerleşmesi yazınsal mekân kurgusunun temelini oluşturmaktadır. Duvar inşa etme, durdurulamaz bir gereksinimin işaretidir. Juan José Saer'ın “Görgü Tanığı”nda temsil edilen yazınsal mekân kurgusu, kontrol edilebilen ana aks etrafında kademeli ve geometrik formlarla desteklenmiştir. Referans noktalarının olmayışı, kendine has bir mimari dil geliştirmiştir. Ana omurganın sonunda yer alan dairesel formlu merkezi çekirdek, düğüm noktası niteliği kazanmıştır. William Faulkner'ın "Döşeğimde Ölürken"inde temsil edilen yazınsal mekânda çeşitli anlatıların bir arada olduğu görülmektedir. Birbirinden farklı yönlere doğru uzanan göstergeler mekânsal bir bütünlük oluşturmaktadır. Farklı an'ların izlerinin üst üste binmesiyle birlikte karmaşık bir görünüm hâkimdir. Mimari çizim ve eskiz çalışması yoluyla temsil edilen mekân kurgusu, akılda canlandırma ve yeniden sunma işlevlerine karşılık gelmektedir. Mekânsal izler ve hayal gücü, hafızanın aktarımına işaret etmektedir (Şekil 3). 

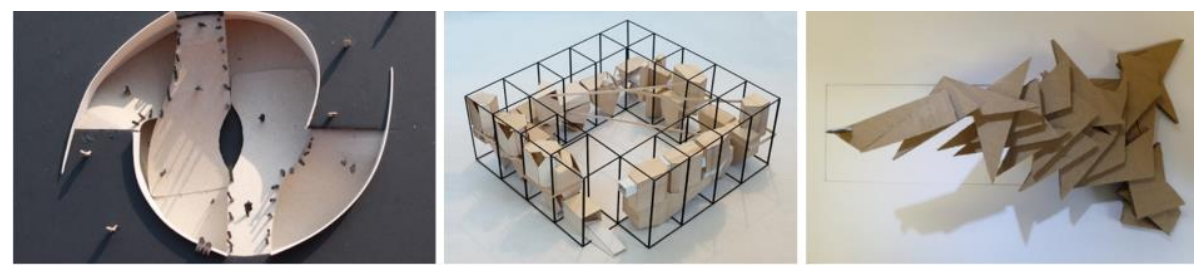

Şekil 4. Ernest Hemingway'ın “Beyaz Fillere Benzeyen Tepeler"; James Joyce'un “Ulysses"; Stefan Zweig'ın "Satranç" Metinleri Bağlamında Yazınsal Mekânın Görsel Temsili

(LabLitArch, 2017)

İlk modelde, iki kişi bir çember içinde dolaşarak çıkmayı hiç beklemeden sonsuza dek sohbet etmektedir. İnsanlar ve yer arasındaki duygusal bağın, kentsel deneyimin ve hafızanın önemli bir parçası olduğu görülmektedir. Karışık görünen ama bir o kadar da birbirine dokunmayan yollar, sadece mekânın özüne odaklanmaya yardımcı olmaktadır. İkinci modelde oluşturulan yazınsal mekânın dili, gerçekçilikten soyutlamaya, ana karakterlerin değişen rollerine ve okuyucunun zamansal geçişlerine dikkat çekmektedir. Dış boşluk çerçevesi, metin içindeki zaman modüllerini yansıtmaktadır. Her bölüm, günün farklı bir zamanını temsil etmektedir. Okuyucu, bu modül içerisinde hareket ettikçe, hacimler açılmaya ve kırılmaya başlamaktadır. Üçüncü modelde, üçgen zorluklar arasında sağlam bir adım bulmak için dikkat edilmesi gereken merdivenler, insan doğasının dayanıklılığına, değişebilirliğine ve esnekliğine vurgu yapmaktadır. İçerideki karanlık tarafa gitmeye cesaret eden kişi, yansıma havuzunda kendi içine bakmakta ve kendi kimliğini kabul etmektedir. Maket ve aksonometrik perspektif aracilığ1 ile temsil edilen mekân kurgusu, dikkat çekme, yönlendirme ve soyutlama işlevlerini yansitmaktadır. Mekânsal dügümler ve zihinsel işaretler, hafızanın aktarımında etkin rol oynamaktadır (Şekil 4). 

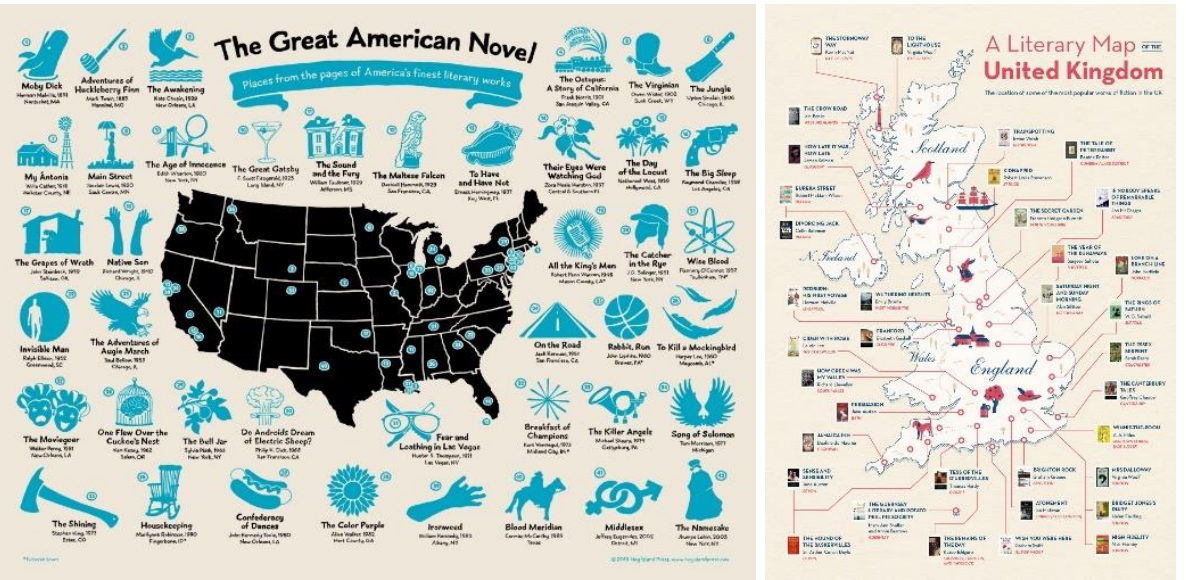

Şekil 5. Yazınsal Mekân Anlatısı (Kath, 2018; Kowalczyk, 2018)

Şekil 5’deki yazınsal mekânların görsel temsilleri, döngüsel ve tekrarlara dayalı bir anlatı niteliğindedir. Kentsel mekânın anlamı ve hissi üzerine derinlemesine bir analiz yapılmıştır. Grafik motifler ve kolaj yardımıyla temsil edilen mekân kurgusu, duygusal durumu ortaya çıkarma ve soyutlama işlevlerine karşılık gelmektedir. Semboller, çağrışımlar, düşsel imgeler ve deneyimler aracılığıyla hafızanın ifade edilmesi, aktarılması ve kalıcılık kazanması söz konusudur.
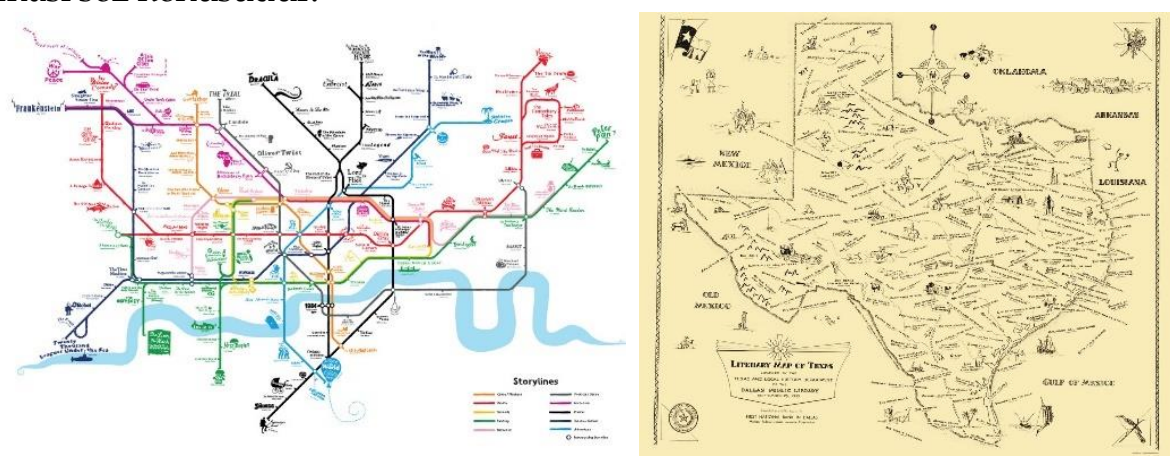

Şekil 6. Yazınsal Mekânın Güzergâh Haritası (Kowalczyk, 2018)

Şekil 6'da farklı edebi metinlerin yere özgü anlamsal, yapısal ve biçimsel yönlerden analiz edilmesi sonucunda, metinlerarası ilişkiler de göz önüne al1narak güzergâh haritası oluşturulmuştur. Londra'nın simgesel metro hattı üzerinde hikâyeler arasında yolculuğa çıkılmıştır. Benzer şekilde, Teksas'ın kendine özgü kültürünü yansıtan yazınsal mekânları arasında bağlantılar kurularak hafıza koridorları yaratılmıştır. Geçmişten günümüze dek varlığını sürdüren mekânsal göstergelerin ve gündelik tekrarların yanı sıra izleri 
kaybolmuş mekânlara da rastlamak mümkündür. Metinlerin temsiliyeti, kodlar ve imgeler aracılığı ile aktarılmıştır. Hikâyelerin göstergebilimsel anlatısı, kentin farklı seslerini, görüntülerini ve zamansal katmanlarını ortaya çıkarmakta, geçmişten ve hafızadan izler taşımaktadır.

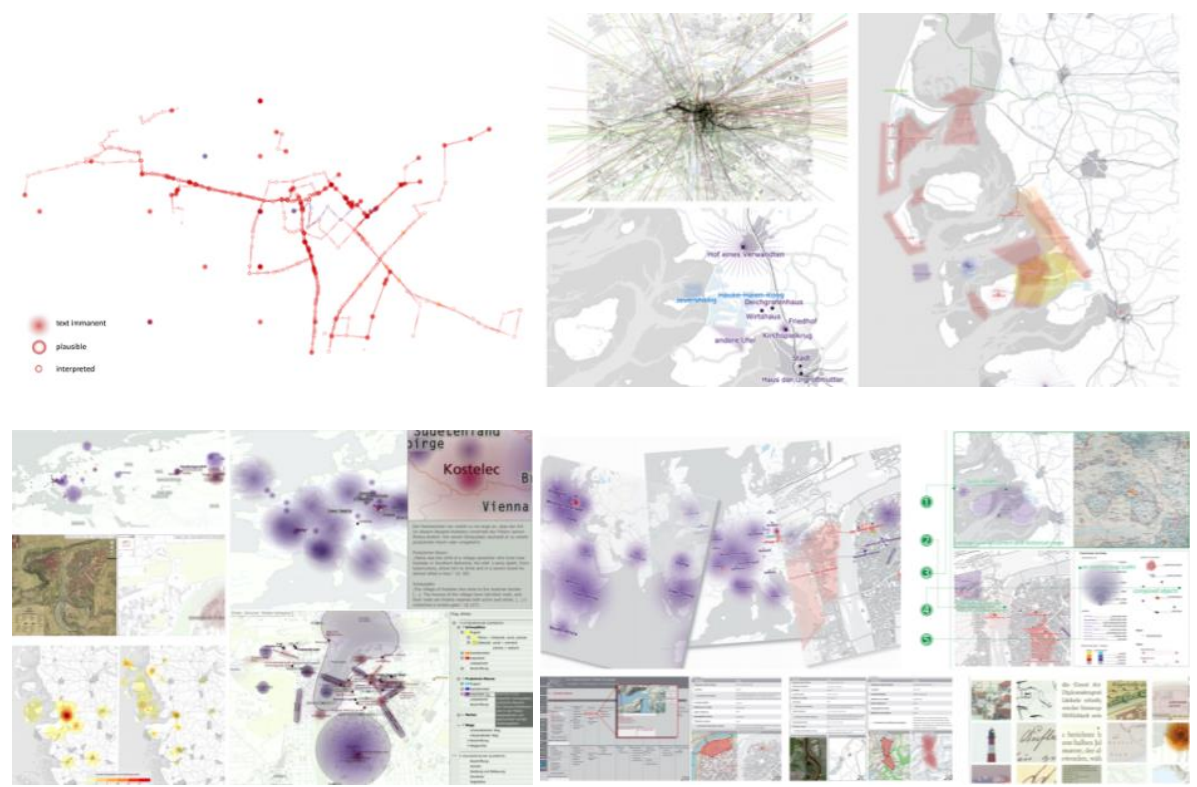

Şekil 7. Etkileşimli Dijital Platformda Yazınsal Mekânın Görsel Temsili (Literary Atlas of Europe, 2012).

Şekil 7'de, bölgeler arasındaki bağlantıların kurgulanmasından, önemli yaya akslarının belirlenmesine kadar birçok kentsel strateji ve eylemin belirlenmesinde edebi metinler etkin bir rol üstlenmiştir. Analiz, tasarım ve karar alma aşamalarında metinlerin bir araç olarak kullanılması ile birlikte sözel, düşünsel ve kurgusal anlamda mekâna zengin bir içerik kazandırılmıştır. Şehir planları aracılığı ile etkileşimli web arayüzünde temsil edilen mekân kurgusu, bilgilendirme, betimleme ve ifade etme işlevlerini yansıtmaktadır. Hafızanın hikâyeler, mekânsal deneyimler ve toplumsal işaretler aracılığı ile aktarılması ve kalıcılık kazanması söz konusudur. 
Tablo 1. Seçilen örneklerin görsel temsil, bağlam, işlev ve hafıza taşıyıcısı çerçevesinde incelenmesi.

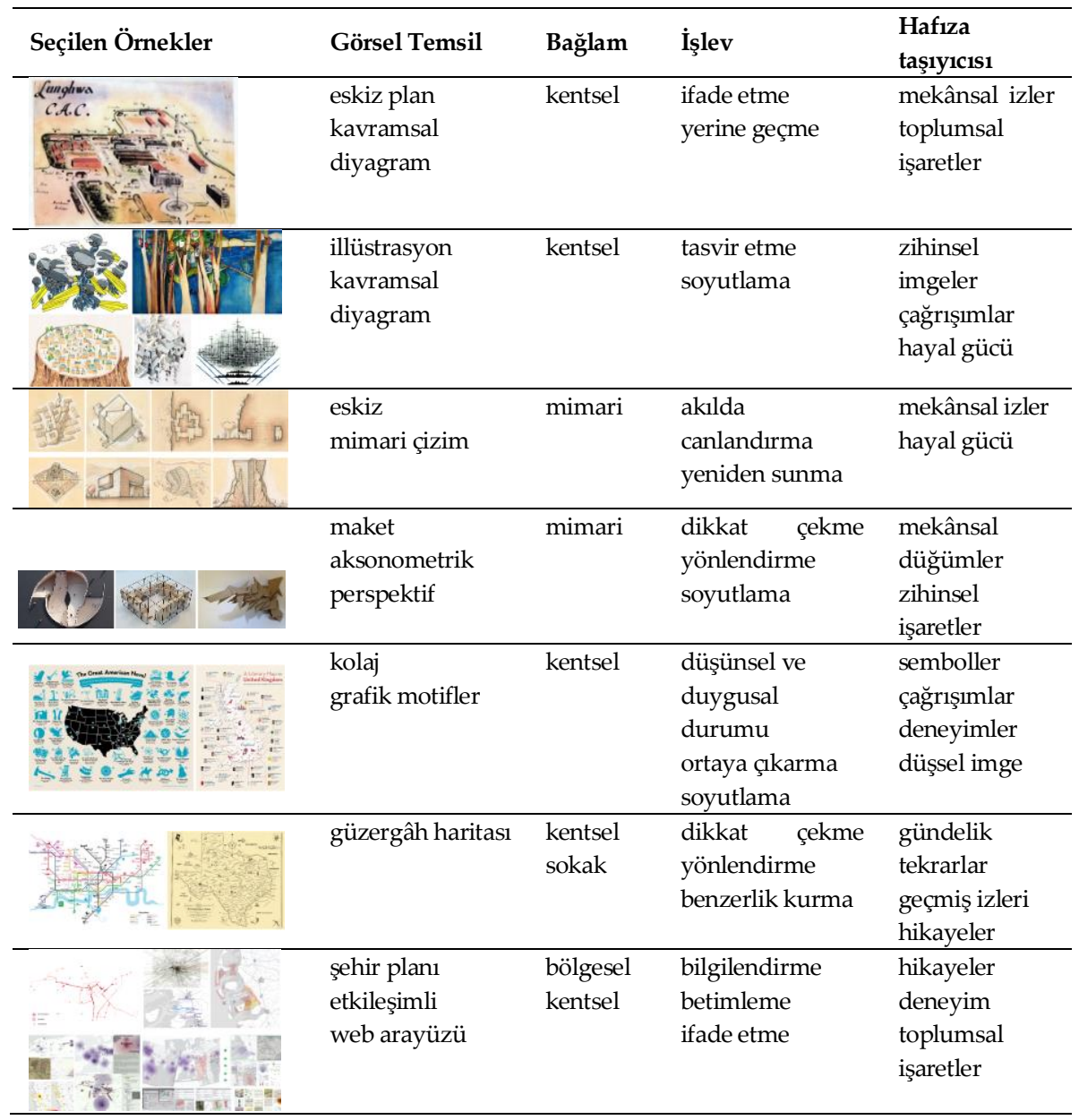

\section{Sonuç ve Değerlendirme}

Kentsel ve mimari düşünce sistemi yazınsaldır (Derrida, 1997). Kentsel/mimari mekânın edebiyatla olan ilişkisi, anlama, hayal etme, üretme ve tasavvur etme becerisini geliştiren önemli birer araçtır. Yazınsal mekân üretimi, insanın düşünceleri, anıları ve düşleri için en büyük birleştirici güçlerden biridir. Bu bağlamda, yazınsal mekânların tasviri ve düşünsel çerçevesi, tasavvur etmenin bir aracına dönüşmekte, düşünce çekirdeğinin özü, mekânın hafızasını yaratmaktadir. 
Barthes'in (2005) kentsel dili okuma alışkanlığı, Hall'ın (1966) mekânı algilama ve öğrenme sürecine metinleri dâhil etmesi, Foucault'nun (1999) söylemsel olmayan hiçbir mekânın olmadığına yönelik savı mimari ve kentsel bilginin üretiminde göstergebilimsel çözümlemenin önemli bir araç olduğunu göstermektedir. Yazınsal mekânın anlatısı, mekânın almaşık anlamlar kümesini (yoruma dayanan, akılda tutulan, gönderme yapılan, üst üste gelen, silikleşen) ortaya çıkarmaktadır (Fairclough, 1992). Kentsel/mimari tasarım sürecinin yazınsal betimlemelerle harekete geçirilmesi ve uyarılması hafızanın mekânda yerleşmesine olanak sağlamaktadır.

Bu çalışma, edebiyat, mekân ve hafıza arasındaki ilişkiye odaklanmaktadır. Yazınsal metinlerin kentsel/mimari mekânı sorgulama, tasarlama ve çözümleme aracı olarak kullanılmasının ve temsil edilmesinin önemini vurgulamaktadır. Bu çerçevede, yazınsal mekânın göstergebilimsel anlatısı, seçilen farklı örnekler üzerinden incelenmiştir. Bu örnekler, sundukları farklı görsel temsil biçimleriyle hafızanın barındırdığı anlamları ortaya koymaktadır. Metinde sorgulama aracı olarak üretilen anlam, tasarım sürecine esin kaynağ olmaktadır. Kentsel/mimari mekânın üretimine doğrudan katkı sağlamaktadır. Üst üste eklemlenerek birbiri ile örtüşen metinlerin, imgelerin, mekânların ve farklı temsil biçimlerinin çok sesliliğini yansıtmaktadır. Zaman içerisinde yok olmuş mekânsal ve toplumsal izleri hafızaya kaydetmektedir. Geçmişi arşivlediği kadar geleceğe dair öngörüler de sunmaktadır. Sosyal ve kültürel ifade veya inşa aracı olarak kullanılmaktadır. 


\title{
Extended Abstract
}

\section{Semiotic Narrative of Literary Space in the Intersection of Memory}

\author{
$*$ \\ Tuğçe Gürleyen \\ ORCID: 0000-0001-6091-8524
}

Spaces consist of various indicators that feed from each other or hide in successive due to their multi-layered structure. Spatial codes and images that infiltrate urban life and take place in minds are related to the meaning and memory of the city. Urban coding that are formed involuntarily and unintentionally in the collective memory of the society continue their existence with the language used in living spaces that produce their own characteristic texts. While the ability to understand and use language connects experiences and actions, it also offers new spatialities that correspond to the reproduction of values and meaning.

Literary texts, which have rich connotations and various images, correspond to the formation, transferring and production of different layers and stories. Literary texts carry many things that have disappeared over time by recording them in their memory. Continuing the spatial traces that are destroyed, lost or forgotten through texts keeps the memory alive. In this context, literary fiction acts as a text that increases the relationships between memory and spaces. It creates new insights by penetrating the layers of spatial meanings.

The relation of urban/ architectural space with literature is an important tool that develops the ability to understand, imagine, produce and envision. The production of literary space is one of the biggest unifying forces for human thoughts, memories and dreams. The development of literary texts as a means of questioning the urban/architectural space offers a wide range of study and resources. In addition, literary texts, which are an important form of expression of memory, can be used instrumentally to understand the reproduction of space. Narrative analyses reveal the alternate set of meanings of the space (based on interpretation, kept in mind, referring, overlapping, 
and become indistinct) (Fairclough, 1992). Thus, activating and stimulating the urban/architectural design process with literary descriptions allow the memory to be settled in the space.

Literary space is a verbal and visual representation of various characters and actions through language. Texts as a way of creating space are reconstructed in everyday life. The reconstruction of the space created in the text depends on the interpretation's appropriation process and the power of creating images. In other words, the spatial narrative is perceived not only as the author shapes it, but through the images created by the interpreter, and reproduced depending on the semantic integrity of the articulated images. Therefore, while experiences emerge the dynamic structure of texts that create spaces within themselves, the survival of the text and its existence with spaces is possible with memory.

The strong interdisciplinary nature of linguistic theory (structuralism, deconstruction, and semiotics) has expanded the boundaries of academic studies. Reading the information produced on urban/architectural space through literary texts is one of the linguistic approaches discussed in urbanism research. Spatial readings, led by the structuralist approach, mark the structure of a city and aim to analyse and write out through codes. Deconstructive understanding emphasizes that texts do not have a single and absolute meaning. It cares about reaching the traces of the parts that make up the language and understanding the relationship between the signifier and the signified. In other words, the deconstruction method is about understanding how the whole is constructed. The idea that every phenomenon that produces meaning is text (Barthes, 2005; Lefebvre, 2004; Ricoeur, 2010) has expanded the boundaries of semiotic approach. Social signs, codes and node points evaluated in an intertextual context are discussed within the scope of linguistic studies. Visual representations, which constitute an important step of semiotics studies, enable the analysis of urban meaning and memory throughout a process by separating different layers, and the expression, transferring and permanence of language through symbols.

This study focuses on the relationship between literature, space and memory. It emphasizes the importance of adding textual fiction to urban context and combining the imaginative fiction of literature with the narrative power of design. It reveals the necessity of using and representing literary texts as a tool for questioning, designing and analysing urban/architectural space. Within the scope of the study, the semiotic narrative and visual representations of literary texts are examined within the framework of context, 
function and memory carriers through selected examples. Sketch plans, conceptual diagrams, illustrations, architectural drawings, models, axonometric perspectives, graphic motifs, collages, route maps, city plans and interactive web interfaces are examples of different visual representations. These examples reflect different contexts, including regional, urban, architectural and street scale. They correspond to the functions of expressing, replacing, depicting, abstracting, visualization, re-presenting, drawing attention, directing, revealing the intellectual and emotional situation, establishing similarity, informing and describing. Spatial traces, social signs, mental images, connotations, imaginations, spatial nodal points, experiences, senses, daily repetitions, past traces and local stories are analysed as memory carriers.

In conclusion, the semiotic narrative of literary texts is an effective tool that creates common ways of understanding social life and space, and corresponds to the reproduction of memory (Bruner, 1986; Ricoeur, 2010; Wertsch, 2002). It reflects the multivocality of spaces, images and different modes of representation overlapping each other by articulating in the context of remembering, meaning and reconstructing lived experiences. Visual representations of semiotic narrative are a way of reconstructing the past, conveying individual and collective experiences, and making sense of cross-layer relationships (Crang, 1996). They record the spatial and social traces that have disappeared and ignored on memory. They provide predictions about the future as well as archiving the past. They are used as a means of social and cultural expression or construction. They reveal the meanings of memory with the different representation form, and directly contribute to the production of urban/architectural space.

\section{Kaynakça/References}

Aktulum, K. (2000). Metinlerarası ilişkiler. Ankara: Öteki Yayınevi.

Bachelard, G. (1996). Mekânın poetikası. İstanbul: Ayrıntı Yayınları.

Barthes, R. (2005). Göstergebilimsel serüzen. İstanbul: Yapı Kredi Yayınları.

Breuer, M. (1986). XX. Yüzyll mimarlğ̆ına estetik açıdan bakış. Ankara: Yaprak Kitabevi. Borgeaud, P. (1999). Mitin belleği ile tarihin unutkanliğı. Ankara: Dost Kitabevi.

Bruner, J. S. (1986). Actual minds, possible worlds. Cambridge, MA: Harvard University Press.

Calvino, I. ve Atakay, K. (1994). Amerika dersleri: gelecek binyıl için altı öneri. İstanbul: Can Yayınları.

Crang, M. (1996). Envisioning urban histories: Bristol as palimpsest, postcards, and snapshots. Environment and Planning A, 28(3). 
Çağlar, N.,Ultav, Z. (2004). Emile Zola yazınından mimari/kentsel mekâna dair okumalar ve düşünceler. Hacettepe Üniversitesi Edebiyat Fakültesi Dergisi, 21 (1).

Çağlar, N., Tuna Ultav, Z., Boyacıoğlu, E. (2013). Sevgi Soysal ve Yenişehir'de bir öğle vakti romanından mimari/kentsel mekâna ilişkin çıkarımlar. Dokuz Eylül Üniversitesi Edebiyat Fakültesi Dergisi, 2 (3).

De Certeau, M. (1984). The practice of everyday life. University of California Press, Berkeley.

Deleuze, G. (1994). Difference and repetition. New York: Columbia University Press.

Derrida, J. (1997). Of grammatology. Baltimore and London: The Johns Hopkinson University Press.

Eco, U. (2009). Anlatı ormanlarında altı gezinti. İstanbul: Can Yayınları.

Fairclough, N. (1992). Discourse and social change. Cambridge: Polity press.

Foucault, M. (1999). Bilginin arkeolojisi. İstanbul: Birey Yayıncılık.

Genette, G. (1997). Palimpsests: literature in the second degree. Lincoln: University of Nebraska Press.

Hall, E. T. (1966). The hidden dimension. Garden City, NY: Doubleday.

Havik, K. (2006). Geleefde ervaring, gelezen plekken: naar een stedelijk alfabetisme/Lived experience, places read: toward an urban literacy. Oase: journal for architecture, 70 (2006).

Havik, K. (2014). Urban literacy: reading and writing architecture. NAI Publishers, Rotterdam.

Hegel, G. W. F. (1998). Aesthetics: Lectures on fine art (Vol. 1). Oxford University Press.

Heidegger, M. (2008). Ontology-the hermeneutics of facticity. Indiana University Press.

Kath (2018). These literary maps of the United Kingdom bring novel locations to life. 11 May1s 2020 tarihinde, http://forreadingaddicts.co.uk/literary-places/these-literary-mapsof-the-united-kingdom-bring-novel-locations-to-life/26885 adresinden erişildi.

Kowalczyk, P. (2018). Prepare for adventure: 17 literary maps to explore. 11 Haziran 2020 tarihinde, https://ebookfriendly.com/literary-maps-to-explore adresinden erişildi.

Kristeva, J. (1980). Desire in language: a semiotic approach to literature and art. New York: Columbia University Press.

LabLitArch, (2017). Workshop projects. 11 May1s 2020 tarihinde http://lablitarch.com/projects adresinden erişildi.

Literary Atlas of Europe (2012). Mapping and analysing the geography of fiction with interactive tools. 11 Mayıs 2020 tarihinde, http://www.literaturatlas.eu/en adresinden erişildi.

Lefebvre, H. (1993). The production of space. Blackwell: Oxford.

Lefebvre, H. ve Regulier, C. (2004). Rhythmanalysis: space, time and everyday life. London: Continuum.

Merleau-Ponty, M. (2013). Phenomenology of perception. Routledge.

Moloney, T. S. (1983). The semiotics of Roger Bacon. Mediaeval Studies, 45.

Pallasmaa, J. (2012). The eyes of the skin: architecture and the senses. John Wiley \& Sons.

Peirce, C. S. (1991). Peirce on signs: writings on semiotic. UNC Press Books. 
Pericoli, M. (2017). The literary architecture series. 11 Mayıs 2020 tarihinde http://lablitarch.com/the-literary-architecture-series adresinden erişildi.

Ricoeur, P. (2010). Time and narrative. London: University of Chicago Press.

Rossi, A. (1983). The architecture of the city. Cambridge: Mit Press.

Saussure, F. (1998). Genel dilbilim dersleri. İstanbul: Multilingual.

Sellars, S. (2012). Zones of transition: Micronationalism in the work of J.G. Ballard 11 May1s 2020 tarihinde, http://ballardian.com/zones-of-transition-micronationalism-inthe-work-of-j-g-ballard adresinden erişildi.

Spurr, D. (2012). Architecture and modern literature. The University of Michigan Press.

Stein, S., Haldenbay, E. ve Roth, E. (1990) New Directions in Architectural Research. Canadian Symposium on Architectural Research, University of Calgary.

Temple, E. (2017). Art inspired by Italo Calvino's Invisible Cities. 11 Mayıs tarihinde, https://lithub.com/art-inspired-by-italo-calvinos-invisible-cities adresinden erişildi.

Thomson, S. (1996). Places within and without: memory and literary imagination, memory and architecture. University of New Mexico Press.

Tümer, G. (1981). Mimarlıkta edebiyattan neden ve nasıl yararlanmalt?. İzmir: Ege Üniversitesi.

Tümer, G. (1984). Insan-mekân ilişkileri ve Kafka. İzmir: Sanat-Koop. Yayınları.

Uz, F. (2007). Mekânın yazınsallı̆̆ı ve bir Taşkışla deneyimi. İstanbul Yayın.

Wertsch, J. V. (2002). Voices of collective remembering. Cambridge University Press.

Werth, P. (1999). Text worlds: Representing conceptual space in discourse. Prentice Hall.

Zima, P. (2000). Manuel de sociocritique. Editions L'Harmattan 